\title{
Foreign Languages and the Problem of African Identity: The Nigerian Situation
}

\author{
Oluchukwu Felicia Asadu \\ http://dx.doi./org/10.4314/ujah.v19i2.9
}

\begin{abstract}
The issue of identity seems to have taken the form of a mirage with the continuous influx of foreign languages into the developing world. Despite the heterogeneous linguistic situation itself the continent has always been open to foreign languages as a means of effective communication between peoples and cultures both within and outside the continent. This paper examines the influence of foreign languages on African identity with a special reference to Nigeria and some francophone countries. It also explores ways in which the African man can maintain his cultural identity in spite of foreign influence.
\end{abstract}

\section{Introduction}

Foreign languages have long come to stay in African counties. This is largely because of colonialism and the complex linguistic nature of the country. Africa had varied patterns of governance until the coming of Europeans through colonialism. French and English, historically, were languages of business transactions and government during colonialism. France controlled eleven of the sixteen countries in West Africa, and ruled her African colonies as an extension of France. This was shown by 'french-frying' Africans via its politico-social policy of assimilation. All French West African Leaders - Senghor, Boigny, Sekou Toure etc. as well as scholars were educated in France and were French citizens and 
served in French National Parliament in Paris. At independence, France granted her West African nationals patronage in every field. The majority of other African countries were colonized by Great Britain and administered through indirect rule. French is the official language of the remaining non-English speaking Africa apart from the few Arabophone, Lusophone or Hispanophone states.

This paper is divided into five sections. The first section looks at the relationship between identity and language in the African setting. Section two gives a brief historical account of European colonisation in Nigeria and her francophone neighbours. Section three discusses the effect of French and English languages. The issue of African identity crisis is taken up in section four while section five forms the summary and conclusion.

\section{Relationship between Language and Identity}

"Language is used to express role relationships between individuals. " Generally and in every society, language are a tool and a useful instrument for building relationships between individuals. In the Nigerian setting, for example the linguistic situation is very complex. It is heterogeneous but each ethnic group identifies itself with its own indigenous language, it is part of our ethnic identity even before the coming of the Europeans. That is how our identity is expressed through the language we use in the country. Building on what Sterling said above, for example, in Nigeria the Yoruba man from the South West identifies with his fellow Yoruba through language, building this relationship through the use of the Yoruba language. This cuts across ethnic group whereby an Igbo man from the South East or a Hausa from the North who is fluent in the Yoruba language can automatically also build the same relationship with the Yoruba man. Politically the 
Hausa/Fulani had a political system based on emirate system. Here the Emirs are at the helm of government and every Hausa/Fulani persons see him as his overlord. In Igbo land, the Igbo were governed through the kindred (Umunna) 'Umuada' and different age grades. The Yoruba, were governed by Obas through council of Chiefs. In that era, there was no law court and peace and order were maintained.

In the Nigerian setting, generally without the influence of any foreign language, our own indigenous languages reflect our own cultural identity within the country. To avoid a dualistic identity in a person Anshi and Jando say "It is either that an African is an African or if he fails would have his being contradict the laws of thought and in this case also of his being",521. This is the situation in which an African finds himself today. The colonial heritage has so distorted Africa that Rev. Fr. Ehusani termed it "ego distortion" in which an African is seen as neither an African nor a European because he has lost his true identity through foreign language since language and culture are interrelated.

Mbaefo refers to this as the "Cruelest legacy... that brought a confused sense of identity". The African assumes a dual personality and that is why July says that the modern African is a product of "uneasy union of two alien civilizations"3. By trying to make himself appear like a "Whiteman in black skin". Nnoruka in his view on African identity posed a lot of questions and he says:

Africa witnesses a crisis of conscience which impinges greatly on African development. He has failed abysmally to pose to himself the questions. What am I? What kind of entity? What kind of being? What constitutes my person $^{4}$ ? 7 


\section{Brief Summary of European Colonisation in Nigeria and Her Francophone Neighbours}

The Europeans supposedly came to salvage Africa from dark ages and ruled it according to their dictates. To support this Ekwenze says:

The Europeans totally invaded every aspect of the African life and aimed at supplanting all African values with

European ones. They saw themselves as the harbingers of light to a completely dark world ${ }^{5} .331$

They ruled Africa through few of our educated men, the chiefs and others who could understand them and interpret to the masses. There, the interpreter tried to interpret back to people who could not understand the various colonial languages. Till date, an average African who cannot express himself/herself in colonial language is seen as an illiterate, irrespective of his education. These functional foreign languages came to us Africans as a tool for colonization because language and culture are interwoven or inter related. In order for Africans to imbibe the western culture hook line and sinker, free education was given, where the Africans were taught in line with European culture. In essence the European came to develop Africa in line with their own development regardless of its experience, history, cultural traditions and inclinations.

In line with this trend, the British colonized Nigeria and brought their language into the country. The initial introduction of English in Nigeria cannot be ascertained even though there were accounts of trade between European and Africans in which Pidgin English developed as a means of communication to facilitate commerce. The British used their own official English. English 
was imposed on the colonised because the British could not speak African indigenous languages.

British rule and imposition of English language in Nigerian has been summarized in the following words by Odumah:

observed the language of the colonial administration the (civil service) was English not only did the administrators help to spread English language using bureaucratese and officials; but more importantly in their homes they again did in their interaction with domestic staff guards, gardeners, steward".10

The consequence of this imposition is captured thus by Allain:

A people whose language is dominant will typically be dominant politically and or socially, economically and certainly psychologically: that is they will intend to feel themselves dominant, and be resented as such by those who use their language but are not native speakers"398.

This implies that regardless of the number of indigenous language already in existence and being used by the people as part of their cultural identity and inter personal relationship the British impose their foreign language on the society.

\section{Effect of the Imposition of the English and French Languages on Nigerian Identity}

The British ruled through a few tutored Nigerians who acted as interpreters In the South-east of the country for example, these interpreters were called "Nwadisi". Because the interpreters were not proficient in the English language, their interpretation laid or caused a lot of confusion, misunderstanding and even crisis in the 
prevalent self consciousness of the Igbo man. To support this, Achebe told the following story:

When they had all gathered, the white man began to speak to them. He spoke through an interpreter who was an Igbo man, though his dialect was different and harsh to the ears of Mbanta. Many people laughed at his dialect and the way he used words strangely. Instead of saying "myself" he always said "my buttocks" 116 .

The immediate cumulative effect of these changes is captured by Okonkwo's sentiment in Achebe's Things Fall Apart after his (Okonkwo's) return from exile:

Umuofia has indeed changed during the seven years Okonkwo had been in exile. The church had come and lay many astray... Okonkwo was deeply grieved. And it was not, just a personal grief. He mourned for the clan, which he saw breaking up and falling apart" 139 .

It was not just physical change but more importantly the cultural change surprised Okonkwo. This was even used as satire in Igbo comedy "ichoku". There the interpreter mocks the English because he cannot understand the language but in the language which he understands which is Igbo turns to the audience relates to them and they end up laughing and this despite that the judge is an English man and the language used in the court is English .

While this comedy aspect is funny and hilarious, the sad aspect of this whole scenario is reflected in unjust judgments and condemnations. This played a big role in the identity crisis of the average Nigerian who in his country is forced with a language he does not understand and also not his own for a crime he often did not commit. The issue of identity crisis flourishes in such a setting because the Africa in this case the Nigerian is sentenced through a 
foreign language in his own country by a foreigner who does not see the indigenous language as befitting to be used in public life.

From this period onwards, the necessity to learn and master the English language became so pressing that the indigenous languages began to suffer neglect. This situation impacted negatively on the identity of the citizens, up to the present generation. Even now, for example many Nigerians would rather have their children learn English to the detriment of their own indigenous languages. Moreso, when the country itself has English as its national / official language. The Nigeria linguistic situation fits very neatly into Cheik Ahmidou's statement that: "The gun conquers but school helps to perpetuate conquest".

This the school does through language which it uses to further alienate the conquered from their culture, identity, and context. Hence efforts should be made in our various schools to promote our national values on which anchor the major traits of our identity. Citizenship education, vernacular, morality (which has become relative) and culture should be made to be important components of our curriculum. Okodo says:

Nigeria is presently exoglossic. That is to say her national language is imported and it is spoken by a few native speakers who are not a majority in any one part of the country"198.

\section{Foreign Languages and African Identity Crisis}

How this identity crisis is also visibly reflected culturally is evident in our mode of dressing. For example, in the civil service the preference in Nigeria today is for suit and tie despite the hot weather. The fact that language and culture are inter-related is evident in this identity crisis in which the Nigerian presently finds himself, a situation already termed 'ego distortion'. All the above 
notwithstanding the inherited hegemony of the English language can still be utilized to the benefit of the average Nigeria in the world today.

In the area of the study of foreign languages, the problem of inferiority complex is clearly visible. For a long time the Nigeria student who studied a foreign language had the opportunity through the year abroad programme to visit the country whose language he/ she was studying. This programme has been totally scrapped in some cases, while in the others, it has been redesigned because the average Nigerian students never returned home after completion of the programme, he/she rather preferred the foreign country to his own. Thus, the study was more for economic reasons than anything else.

Many Africans forbid their children from speaking vernacular in their families because their parents do not encourage the use of indigenous languages. For example in a far village of Uga, one hears children speaking English and not speaking the language of the immediate environment. The indigenous languages of Africa are fast disappearing. Also the preference for foreign languages in school Certificate Examination and our Universities cannot be left out. In Nigeria, for example, before one is given admission into any higher institution one must have a credit in English Language not our indigenous Language. In all the post U.M.E. Exams English Language is compulsory for everybody taking the exam irrespective of his discipline.

The principle of Identity according to Cop and Cohen states that if a statement is true, then it is true" 372 . Literally this is referred as tautology similarly the issue of identity with respect to human beings means that if a person is an African then the person is an African. A person can never be an African and a European or 
half African and half European this was what Leopold Sedar Senghor, Leon Contran Damas, Aimé Césaire and so many other blacks who went to France kicked against through their individual works. These people mentioned above refused and fought through Negritude to promote the real African Identity even in France and they succeeded. Somebody like Leon Contran Damas who was a half cast "Mulatre" refused the kind of education given to him by his white mother but loved the education of his black father, he wrote "Ma mère voulant d'un fils très do très ré..."

\section{The Advantages of English and French Languages in Nigerian Today}

Even though the British colonised Nigeria, the predominance and importance of the English language today can be traced to the emergence of United States as a super power at the end of the Second World War. Today, the English language has more second language speakers than any other language in the world. This is mainly because the language serves immensely as the language of business. To support this, Ugorji said: "from pre-colonial times to present day, English has been the language of administration, government, judiciary, science and technology, external communication, education, wider communication."15

The average Nigerian has the advantage that English is officially the main language of instruction in schools, in the public service, in government etc. Unlike his counterparts from nonEnglish speaking African countries, for example, Ethiopia, the average Nigeria does not need to learn this world business language extraneously. He can take advantage of this colonised linguistic heritage in the sense that, he is open to study in America, the Uk, Australia, New Zealand, English - speaking Canada etc. where English is the language of instruction. 
In the diplomatic setting, he is also open to offer, that demand competence and proficiency in the English language. The ability to read international journals, do research etc. are possible to an average Nigerian because of English. Also technological advances came first in English language before being translated into other foreign languages. Foreign languages have always bridged the communication gap among world bodies technologically, politically, culturally, socially, economically etc.. Indeed English and French have become languages of world bodies like UNO, UNESCO and WHO. The united Nations through its General Assembly, stipulates in the resolution of $1^{\text {st }}$ February 1946 that only English and French have the status of working languages; so all other interventions and texts will be obligatorily interpreted or translated into these two languages. There is therefore a bilingual situation in the UN a world body of which Nigeria is a member country.

Each country has its various reasons why these foreign languages are being studied. In Cameroun for instance, the teaching of English has become a second official language after French for the purpose of national unity. In Ghana, an English speaking country, French is learned. The reason according to Brain is:

To enable Ghanaians to communicate freely with the people of the neighbouring countries whose official language is French and to give the pupil a basic knowledge which will then assist him with more thorough study of languages" 22

In Nigeria which is also an English speaking country, French has become the second official language because of the the Nigerian government has realized the importance of French to her 
technological, economic and cultural development. That is why General Sani Abacha in August 1997 made French the second official language in Nigeria. To support this David says:

Les peuples nigérians et d'autres pays Anglophones d'Afrique ont besoin de français pour communiquer non seulement avec leurs voisins francophones mais avec la France et les autres pays francophones sur le plan économique, socio-culturel, politique et technologique »15

The Nigerian citizens and other English speaking Africans need French Language for better communication not only with their francophone neighbours but with France and with other francophone countries on economic, sociocultural, political and technological level.(Translation mine $)^{14}$.

If language is a means of communication, Nigerians need this language in order to communicate effectively with their neighbours. Onyemelukwe posits:

Les Anglophones se sont rendus compte qu'ils sont entourés par les francophones et qu'on ne peut plus parler de l'unité africaine sans d'abord pouvoir communiquer avec ses voisins immédiates et que ceux-ci étaient les francophones $\gg 15$

The English speaking countries are aware that they are surrounded by the francophone countries and that the unity of Africa cannot be spoken of without first being able to communicate with the immediate neighbours and these neighbours are francophone.(Translation mine) ${ }^{15}$ 
French language is very indispensable to business men who transact businesses with French speaking countries. To support this, Aderemi posits:

Businessmen will be able to conduct their affairs with their, colleagues in French-speaking African countries, and in France without encountering any difficulties in communication $^{16}$,

It is an undisputable fact that Africans need these foreign languages in order to thrive internationally but we should learn them with caution.

\section{Summary and Conclusion}

Despite contrary opinion with regard to the importance of English for national development in Nigerian the English language in Nigeria serves as an important lingua franca because of the complex and multi-lingual situation in the country. It resolves the problem of one indigenous language being imposed on others, a situation that could result in political crisis.

In addition, the learning of more foreign languages should be encouraged in Nigeria. At the same time, our own indigenous languages should be strengthened through research especially in the area of comparative linguistics. This is because it is only through research and the understanding of one's own language as well as knowledge of foreign languages that one would be in a position to deliberate on language issues. The pre- requisite knowledge of one's own indigenous language is actually the foundation for a strong self consciousness and confidence in matters that involve identity and language in general. There is a popular Igbo adage that says "A mua nwoke ya buru nwoke; a mua nwanyi ya buru nwanyi." This means that Africans should retain 
their identity just like Europeans do. There is nothing like individual exhibiting dual identity.

Senghor in admonishing Africans to stop copying or emulating Western values as these would not change who they are by virtue of the colour of the skin as cited by Mutiso and Rohio:

When the French Europeans enforced their policy of assimilation on us, they thus deepened our despair. Earlier we had become aware that assimilation was a failure, we could assimilate Mathematics or the French language, but we could never strip off our black skins or root out black souls" 83

Blacks should have their identity or uniqueness or trait that differentiates them. Despite all efforts made by Leon Damas' mother to make him white, Damas still could not be white. We might reduce ourselves to copycats, stooges and puppets of the alien culture through language learning but the truth is that we cannot change our identity.

\section{Oluchukwu Felicia Asadu \\ Department of Modern \\ European Languages \\ Nnamdi Azikiwe University, Awka \\ asaduoluchukwu@yahoo.com}




\section{Works Cited}

Achebe Chinua: Things Fall Apart England: Heinemann, 1958.

Allan, Keith. Nation, Tribalism \& National language Nigeria's case. Cahiers d'etudes africaine. 71 Xvii - 3, $397-415$. 1978.

Amshi Martin Wang and Jando Francisca "Preserving African Identity in the globalization process" in Essence ps. 52 53. 2008.

Cop, M. \& Cohen C. Introduction to Logic 9th (ed) New Delhi: Hall of India Private Limited 2000, pp372 - 373.

Ekwenze, Peter. "The decade of democracy in Nigeria: A philosophical assessment in The humanities and Nigeria's democratic experience pg. 34,. Rex Charles and Patrick limited, Nimo. 2009.

July R.A. History of the African peoples. New York: Charles Scribner's Sons, , p. 405. 1970.

Mbaefo, L. Towards a Mature Christianity. Enugu: P. 101. 1989.

Mutiso, G.M. \& Rohio, S.W (Eds), Readings in African Political Thought. Nairobi: Heinemann Books. 1955.

Nkumah, K. Conciencism: A philosophy and Ideology for decolonization, London: Panaf Books, 1970, P7.

Nnoruka, S.I. Personal Identity: A Philosophical. Survey, Uyo Modern Business Press Ltd, p.11. 1995.

Odumah, Adama. Nigerian English. Zaria: Ahmadu Bello University Press Ltd. 1987.

Okodo, Ikechukwu "The effects of colonization on the "Igbo language of Nigeria" in Paradise in the Arts Fab Anieh Nigeria Ltd. Okpuno. 2008.

Polly, Sterling, "Identity in language: An exploration into the social implications of Linguistic Variation Texas A \& M University. 
UNESCO, Bibliography of Major Decision, Meetings and Documents related to UNESCO's Activities in the Domain of Mother tongue instruction And Languages. Division of Structure, content, Methods and Techniques of Education UNESCO. Parish, 1981. ED/8L-CoNF 601/4PP.21 - 24. Figures Published in Franco - Nigeria published by (EDUST May 1986). 